\section{The Effect of DNP-coupling and IgA Binding to Salmonella typhimurium 395 MS on Physicochemical Surface Properties and Interaction with Phagocytes*}

\section{EDEBO, T. SKOGH and O. STENDAHL}

Department of Medical Microbiology, University of Linköping, S-581 85 Linköping, Sweden

The virulent and phagocytosis-resistant Salmonella typhimurium 395 MS is hydrophilic and has a very small negative charge, whereas its non-virulent Rdmutant RM10, which is more liable to phagocytosis, is hydrophobic and more negatively charged as studied by partition in aqueous polymer two-phase systems made from dextran, polyethyleneglycol and polyethyleneglycol substituted with hydrophobic (palmitoyl-) and charged (bistrimethylamino $=\left(\mathrm{CH}_{3}\right)_{3} \mathrm{~N}^{+}-$and bissulfo $\left.=\mathrm{SO}_{3}^{-}-\right)$ligands, by hydrophobic interaction chromatopgraphy, and by contact angle measurements. ${ }^{1}$ Changes similar to those observed after $\mathbf{S} \rightarrow \mathbf{R}$ mutation occurred by the binding of antibody IgG to $S$. typhimurium $395 \mathrm{MS}$, whereas SIgA binding to MR10 produced opposite effects.

The present communication describes effects of the coupling of dinitrophenyl (DNP) ligands to $S$. typhimurium $395 \mathrm{MS}$ and the subsequent binding of a mouse IgA myeloma protein with DNP-antigenbinding properties. ${ }^{2}$

* Communication at the Joint Meeting of the Swedish Biochemical and Swedish Biophysical Societies in Uppsala, 28 - 29th November, 1980.
Experimental. To S. typhimurium 395 MS $\left(10^{11}\right.$ cells) in $\mathrm{KI}_{3} 93 \mathrm{MBq}{ }^{125} \mathrm{I}$ was added and incubated for $150 \mathrm{~min}$. After washing the bacteria were suspended in one $\mathrm{ml} 0.2 \mathrm{M} \mathrm{NaHCO}_{3}$, and $10 \mu \mathrm{l} 1 \mathrm{M}$ 2,4-dinitrofluorobenzene (FDNB) added to couple DNP ligands to the bacteria. After different reaction times $0.1 \mathrm{ml}$ aliquots were transferred to $1 \mathrm{ml}$ volumes of $0.2 \mathrm{M}$ glycine $\mathrm{pH} 9.0$ to stop the coupling, the bacteria washed and used as DNPparticles.

The MOPC-315 DNP-binding myeloma protein was purified on DNP-Sepharose 4B similar to Goetzl and Metzger. ${ }^{3}$ Partitioning in two-phase systems, hydrophobic interaction chromatography, interaction with polymorphonuclear (PMN) cells in vitro and clearance after intravenous injection into mice are given in Ref. 1.

Results. Partition in the two-phase systems and hydrophobic interaction chromatography showed increased hydrophobicity and negative charge of DNP-coupled bacteria. DNP-bacteria also showed a greater interaction with polymorphonuclear leukocytes in vitro and clearance after intravenous injection into mice (Table 1). Extensively coupled bacteria were cleared very rapidly also outside the reticulo-endothelial system (RES), such that the recovery from the RES was low.

Binding of the IgA myeloma protein to DNPbacteria had a hydrophobic effect smaller than that of IgG as studied in the above systems. The time for clearance from the blood stream of $50 \%$ of the injected bacteria was increased from $4.3 \mathrm{~min}$ to 6.2 min in the presence of the IgA.

Discussion. The enhancement of the hydrophobicity and the interaction with phagocytic cells by the coupling of DNP to S. typhimurium 395 MS agrees with earlier results ${ }^{1}$ and predictions from physicochemical theory that increased hydrophobicity and interfacial tension promotes

Table 1. Effect of coupling of DNP-ligands to S. typhimurium 395 MS on adsorption to a column of OctylSepharose, partition in aqueous polymer two-phase system, association with PMN cells in vitro, and clearance after intravenous injection into mice (see Ref. 1 for details).

\begin{tabular}{|c|c|c|c|c|c|c|c|}
\hline \multirow{2}{*}{$\begin{array}{l}\text { FDNB } \\
\text { reaction } \\
\text { time } \\
\text { (hours) }\end{array}$} & \multirow{2}{*}{$\begin{array}{l}\text { Bacteria } \\
\text { in void } \\
\text { volume } \\
(\%)^{a}\end{array}$} & \multicolumn{3}{|c|}{ Bacteria in top phase $(\%)^{b}$} & \multirow{2}{*}{$\begin{array}{l}\text { Association } \\
\text { with } \\
\text { PMN } \\
\text { cells }^{c} \\
\end{array}$} & \multirow{2}{*}{$\begin{array}{l}\text { Clearance } \\
\text { rate } \\
(k)^{d}\end{array}$} & \multirow{2}{*}{$\begin{array}{l}\text { Recov- } \\
\text { very }\end{array}$} \\
\hline & & $\mathbf{O}$ & TMA-PEG & P-PEG & & & \\
\hline $\begin{array}{l}0 \\
2 \\
4\end{array}$ & $\begin{array}{l}55 \\
33 \\
13\end{array}$ & $\begin{array}{l}81 \\
26 \\
10\end{array}$ & $\begin{array}{l}86 \\
50 \\
36\end{array}$ & $\begin{array}{l}83 \\
35 \\
20\end{array}$ & $\begin{array}{l}0.03 \\
0.24 \\
0.64\end{array}$ & $\begin{array}{l}0.01 \\
0.17 \\
0.21\end{array}$ & $\begin{array}{r}100 \\
74 \\
35\end{array}$ \\
\hline
\end{tabular}

a Bacteria suspended in $1 \mathrm{M}\left(\mathrm{NH}_{4}\right)_{2} \mathrm{SO}_{4}$ were passed through a column containing Octyl-Sepharose and $\left(\mathrm{NH}_{4}\right)_{2} \mathrm{SO}_{4}$ used for washing the column. ${ }^{b}$ Two-phase system with total conc. $4.4 \%$ PEG $6000,6.2 \%$ dextran 500 . The effects of bistrimethylamino-PEG(TMA-PEG, $12.5 \%$ of PEG substituted) and PEG-palmitate(P-PEG 0.13 mmol palmitic acid per g polymer) were also tested. ${ }^{c}$ Per cent of added bacteria associated with $P M N$ cells after 45 min incubation in vitro. ${ }^{d}$ Rate of disappearance from the blood stream $E_{\mathrm{t}}=E_{\mathrm{o}} \mathrm{e}^{-k t}$. ${ }^{e}$ Recovery (\%) from blood, liver, spleen and lungs. 
interaction with phagocytic cells. ${ }^{4}$ This relationship has earlier been shown for $S \rightarrow R$ mutations in $S$. typhimurium $395 \mathrm{MS}$ as well as for the binding of antibody IgG to the MS bacteria.

The deposition of heavily coupled DNP-bacteria outside the reticuloendothelial system, and the reduction of the clearance by IgA demonstrate mechanisms by which immunocomplex diseases may arise.

1. Edebo, L., Kihlström, E., Magnusson, K.-E. and Stendahl, O. In Curtis, A. S. G. and Pitts, J. D., Eds., Cell Adhesion and Motility, 3rd Symp. Brit. Soc. Cell. Biol., Cambridge Univ. Press, London 1980, pp. 65-101.

2. Potter, M. Adv. Immunol. 25 (1977) 141.

3. Goetzl, E. J. and Metzger, H. Biochemistry 9 (1970) 1267.

4. van Oss, C. J. Annu. Rev. Microbiol. 32 (1978) 19.

Received February 13, 1981. 